Proc. Indian Acad. Sci. (Earth Planet. Sci.), Vol. 95, No. 2, July 1986, pp. 209-221.

(C) Printed in India.

\title{
Physico-chemical conditions of ore deposition in Malanjkhand copper sulphide deposit
}

\author{
S JAIRETH and M SHARMA \\ Department of Earth Sciences, University of Roorkee, Roorkee 247667 , India \\ MS received 27 April 1985; revised 6 November 1985
}

\begin{abstract}
Heating and freezing studies on fluid inclusions in quartz from mineralized quartzfeldspar reef reveal the presence of type $\mathrm{A} \mathrm{CO}_{2}-\mathrm{H}_{2} \mathrm{O}\left(\mathrm{H}_{2} \mathrm{O}>50 \%\right.$ by volume), type B $\mathrm{CO}_{2}$ $-\mathrm{H}_{2} \mathrm{O}\left(\mathrm{H}_{2} \mathrm{O}<50 \%\right.$ by volume), type $\mathrm{C}$ pure $\mathrm{CO}_{2}$ and type $\mathrm{D}$ pure aqueous inclusions. Types $A, B$ and $C$ are primary and/or psuedo-secondary inclusions while type $D$ are secondary. Types $A$ and $B$ homogenize on heating into different phases at similar temperatures ranging between 307 and $476^{\circ} \mathrm{C}$, indicating entrapment from boiling hydrothermal solutions. Type D inclusions homogenize into a liquid phase at temperatures between 88 and $196^{\circ} \mathrm{C}$. Boiling of hydrothermal solutions led to the formation of a $\mathrm{CO}_{2}$-rich phase of low density and salinity that coexisted with another dense and saline aqueous phase with very little $\mathrm{CO}_{2}$ dissolved in it. Ore and gangue mineral assemblage of primary ores indicate that ore deposition was characterized by $\log f_{\mathrm{O}_{2}}=-34.4$ to $-30.2 \mathrm{~atm}, \log f_{\mathrm{S}_{2}}=-11.6$ to $-8.8 \mathrm{~atm}$ and $\mathrm{pH}=4.5$ to 6.5 .
\end{abstract}

Keywords. Fluid inclusion; homogenization; boiling; fugacity.

\section{Introduction}

The Malanjkhand copper sulphide deposit is situated near Padritola, Baihar Tehsil, Balaghat district of Madhya Pradesh. Sharma and Kumar (1969) worked out the stratigraphic sequence of rocks of the area. Rao (1974) carried out ore microscopic studies and proposed a paragenetic sequence of ore-forming minerals. Narang et al (1979) discussed factors controlling ore localization while Tripathi (1979) found enough evidence to name Malanjkhand a copper porphyry deposit. Earlier attempts to understand the physico-chemical conditions of ore deposition are few and controversial. Rao (1974), who studied ore paragenesis indicated very high temperatures $\left(450\right.$ to $700^{\circ} \mathrm{C}$ ) of ore formation. Sharma (1982), based on the analysis of relevant $\log f_{\mathrm{O}_{2}}$ $-\log f_{\mathrm{S}_{2}}$ diagrams for mineral assemblages in ores, indicated equally high temperatures $\left(307\right.$ to $547^{\circ} \mathrm{C}$ ) of ore formation. In the present work, detailed fluid inclusion studies have been undertaken to establish physico-chemical (temperature, pressure, physical and chemical nature of mineral forming media, etc) conditions of ore deposition.

\section{Geological setting}

Archean granite-granodiorite are the main rocks of the area. These have been intruded by a number of basic dykes and are overlain unconformably by younger metasedimentaries of Chilpi Ghat series represented by conglomerates, arkosic grits, quartzites and phyllites. The metasedimentaries have a general ENE-WSW trend with dips of 30 to $50^{\circ}$ due SSE (Rao 1974). 
The most conspicuous geological element in the area is a quartz-feldspar reef occupying a shear zone within granite-granodiorite. The quartz reef is arcuate in shape (see figure 1) with its convexity directed towards east. Strike direction of the reef changes from NNW-SSE in the northern to N-S in the central and NE-SW in the southern parts of the area. The reef is about 10 to $30 \mathrm{~m}$ thick and dips steeply $\left(60^{\circ}\right.$ to $70^{\circ}$ ) due east in the central part.

According to Sharma (1982), within the suite of granite-granodiorite rocks, granodiorite is the most dominant type. Tonalite and quartz-monzonite are present in lesser amounts.

Copper mineralization is confined mainly to the quartz-feldspar reef and has been traced to a strike length of $\simeq 1100 \mathrm{~m}$. Mineralization persists to depths greater than 200 to $300 \mathrm{~m}$. Within the reef, mineralization is irregular, distributed mainly as disseminations, stringers and pockets. Chalcopyrite is the main mineral of primary ores followed by pyrite and magnetite. Molybdenite, sphalerite and cobaltite are present in minor amounts. At places, molybdenite forms relatively richer pockets within the reef. Primary sulphide ores are capped by zones of oxidation and secondary enrichment. Thickness of supergene zones varies from 100 to $110 \mathrm{~m}$ with maximum in the southern block of the ore deposit. Malachite, azurite, goethite, bornite, chalcocite, covellite and native copper are the main minerals of supergene zones.

Primary sulphide mineralization is accompanied by intensive wall rock alteration of granite-granodiorite rocks manifested in the development of pink feldspar, biotite, epidote, chlorite, sericite and kaolinite.

\section{Types of fluid inclusions}

Fifteen polished plates of quartz from the mineralized quartz-feldspar reef were studied using a normal polarized light microscope. Fluid inclusions in quartz are generally very small $(<20-25 \mu \mathrm{m})$ which makes their study rather difficult. Optical microscopy coupled with heating and freezing studies have helped to identify the following basic types of fluid inclusions in quartz: (i) Type A, $\mathrm{CO}_{2}-\mathrm{H}_{2} \mathrm{O}$ inclusions $\left(\mathrm{H}_{2} \mathrm{O}>50 \%\right.$ by volume); (ii) Type $\mathrm{B}, \mathrm{CO}_{2}-\mathrm{H}_{2} \mathrm{O}$ inclusions $\left(\mathrm{H}_{2} \mathrm{O}<50 \%\right.$ by volume); (iii) Type $\mathrm{C}, \mathrm{CO}_{2}$ inclusions and (iv) Type $\mathrm{D}$, aqueous inclusions.

Type $A$ inclusions are characterized by sharp and regular cavity boundaries. Few of these have typical negative crystal shapes. These inclusions are distributed at random within one grain or form small bands cutting across one or more grains (see figure 2). Both the distribution pattern and the inclusion shape suggest that they are primary and/or psuedo-secondary inclusions.

At room temperature these inclusions contain a gas bubble $(10-30 \%$ by volume of the cavity) but slight cooling below the room temperature nucleates a separate phase of liquid $\mathrm{CO}_{2}$ occupying the interface between gaseous phase $\left(\mathrm{CO}_{2}\right)$ and aqueous phase. Some type A inclusions locally contain opaque and/or isotropic solid but such inclusions are extremely rare.

Type B inclusions at room temperature contain a gas bubble $(<50 \%$ by volume of the cavity), but slight cooling below room temperature, nucleates a separate phase of liquid $\mathrm{CO}_{2}$. In shape and pattern of distribution, these inclusions are similar to type $\mathrm{A}$ inclusions and occupy the same clusters of random inclusion or constitute the same bands of inclusions (see figure 2). 


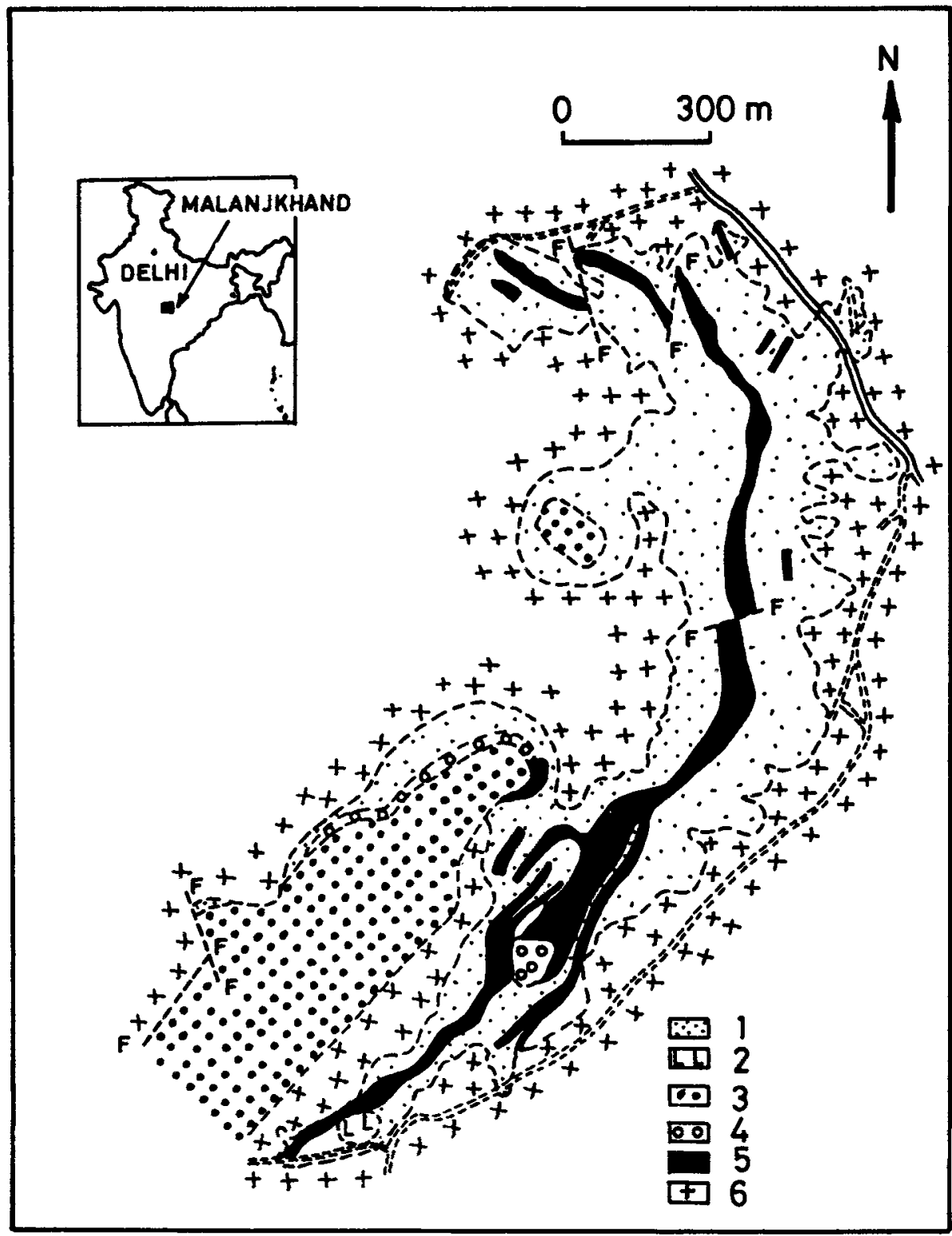

Figure 1. Geological map of Malanjkhand copper deposit, modified after Narang et al (1979), 1. Talus 2. Laterite 3. Arkosic grit, quartzite and phyllite 4. Conglomerate 5. Quartz reef 6. Granite/granodiorite.

Type $\mathrm{C}$ inclusions at room temperature are similar to the so-called dry gaseous inclusions with $\mathrm{CO}_{2}$ occupying the whole volume of the cavity. A thin film of aqueous phase might also be present in them. In some of these inclusions freezing nucleated a separate bubble representing gaseous $\mathrm{CO}_{2}$. Type $\mathrm{C}$ inclusions are closely associated with type $A$ and type $B$ inclusions (see figure 2). All the three types i.e. types A,B,C are thus primary and/or pseudo-secondary inclusions, syngenetic to each other. 


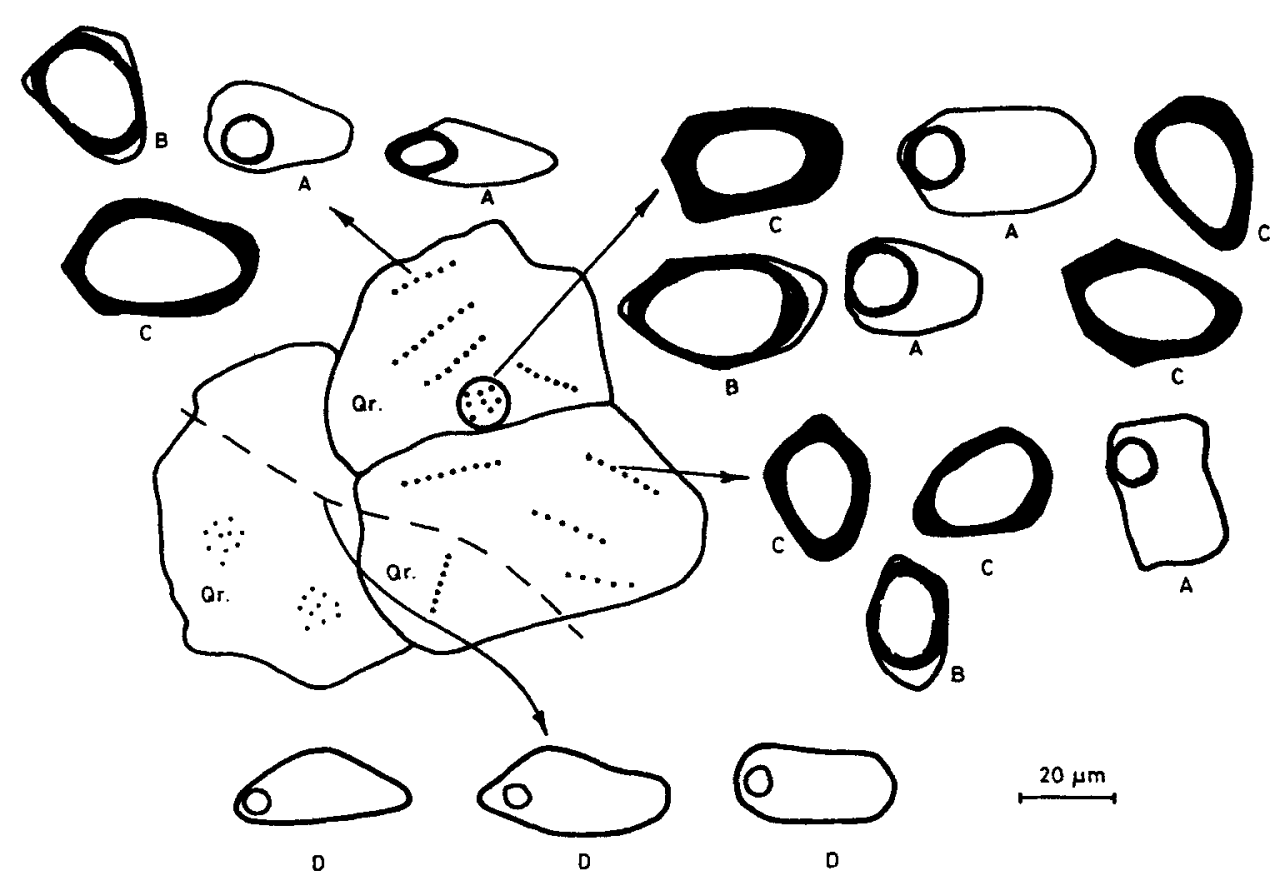

Figure 2. Schematic representation of quartz $(Q r)$ grains showing distribution of types $A, B, C$ and $\mathrm{D}$ inclusions. The dark bubble in all types $\mathrm{A}, \mathrm{B}$ and $\mathrm{C}$ inclusions is $\mathrm{CO}_{2}$ which is surrounded by an aqueous phase. In type $\mathrm{D}$ inclusions bubble is vapour surrounded by aqueous phase.

Type $\mathrm{D}$ inclusions contain at room temperature a gas bubble $(<5 \%$ by volume of the cavity) and are distributed as large bands cutting across large number of grains (see figure 2). They have highly irregular shapes and are thought to be formed due to healing of larger microfractures and hence are secondary. These inclusions are free of solids and do not contain $\mathrm{CO}_{2}$.

\section{Heating studies}

Selected fluid inclusions were heated in a temperature programmable Linkam TH 600 heating freezing system, calibrated carefully using calibration standards recommended by MacDonald and Spooner (1981). Inclusions having irregular cavity boundaries or showing signs of necking down were not heated. Heating was carried out at a constant rate of $10^{\circ} \mathrm{C} / \mathrm{min}$.At temperatures closer to temperatures of homogenization, rate of heating was further reduced to $5^{\circ} \mathrm{C} / \mathrm{min}$. Temperatures of homogenization of various types of inclusions are shown in figure 3.

All type $\mathrm{A}$ inclusions homogenized in two stages. In the first stage gaseous $\mathrm{CO}_{2}$ homogenized into liquid $\mathrm{CO}_{2}$ phase at temperatures between $+17 \cdot 3^{\circ} \mathrm{C}$ and $+30.4^{\circ} \mathrm{C}$ (see figure $3 \mathrm{a}$ ). It should be mentioned that heating at this stage was carried out at constant rates of $0.5^{\circ} \mathrm{C} / \mathrm{min}$ to $1{ }^{\circ} \mathrm{C} / \mathrm{min}$. On further heating all these inclusions homogenized into a liquid phase with the disappearance of gas bubble $\left(\mathrm{CO}_{2}\right.$ phase) at temperatures between $210^{\circ} \mathrm{C}$ and $476^{\circ} \mathrm{C}$ with a mean value of $289^{\circ} \mathrm{C}$ obtained from 
(a)
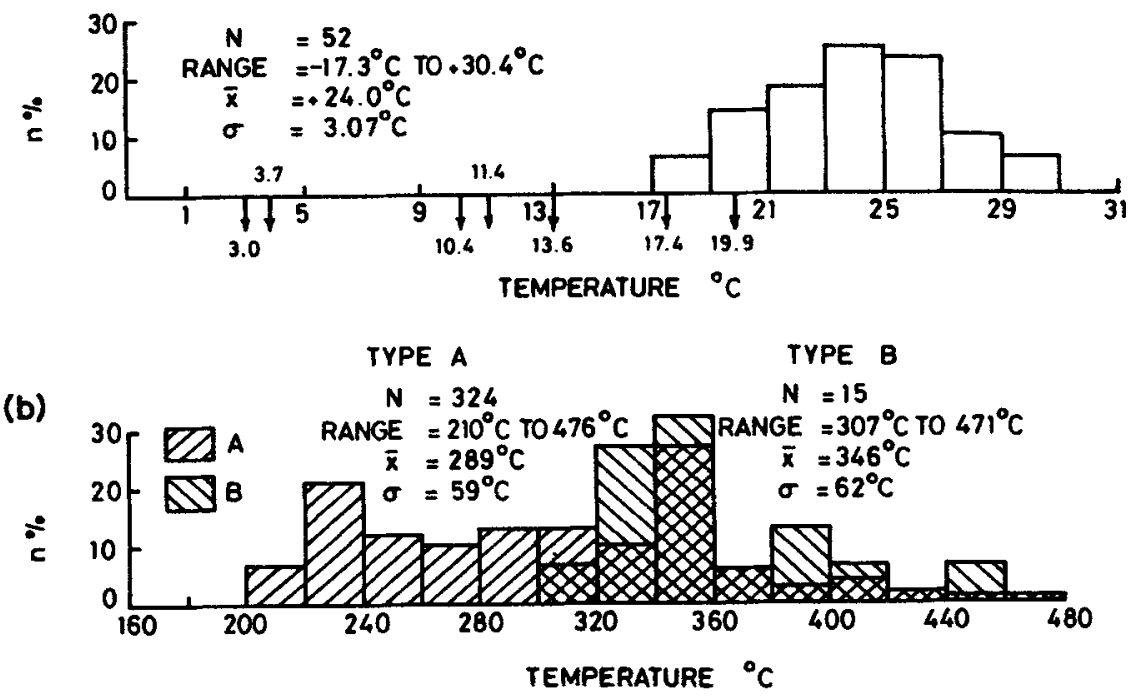

(c)
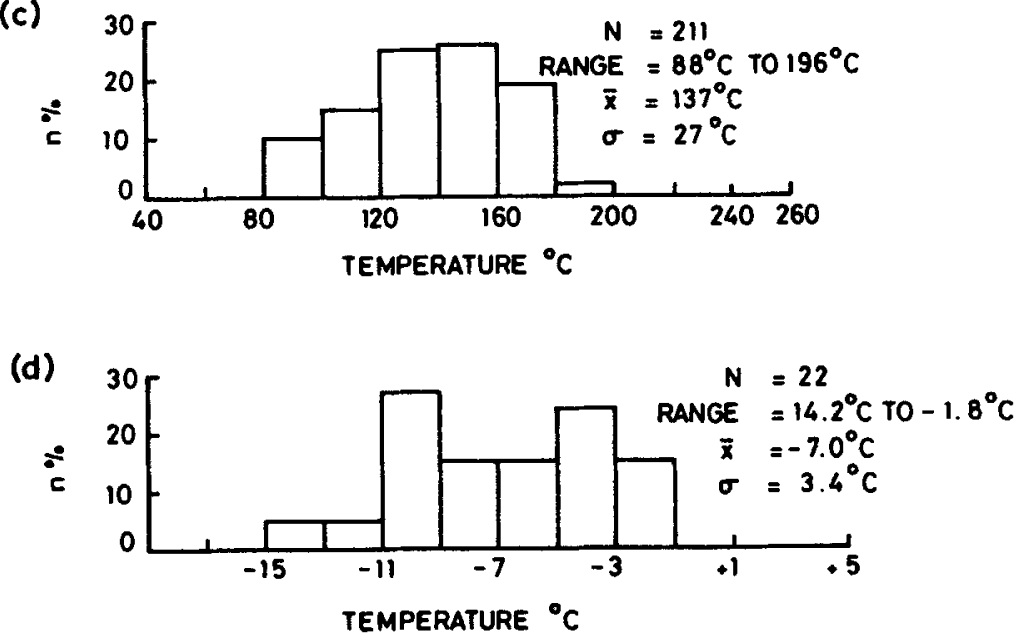

Figure 3. a. Temperature of homogenization of $\mathrm{CO}_{2}$ phases of types $\mathrm{A}, \mathrm{B}$ and $\mathrm{C}$ inclusions. Homogenization temperatures of a few type $B$ and $C$ inclusions are shown as inverted arrows at points corresponding to their temperatures of homogenization. In all inclusions, $\mathrm{CO}_{2}$ phases homogenize by disappearance of gaseous $\mathrm{CO}_{2}$. b. Temperature of final homogenization of primary and/or pseudo-secondary types $A$ and $B$ inclusions. Type $A$ inclusions homogenize into liquid phase while type $\mathrm{B}$ homogenize into supercritical $\mathrm{CO}_{2}$ fluid; $\mathrm{c}$. Temperature of final homogenization of secondary type $D$ inclusions. $d$. Temperature of final melting of ice in type $\mathrm{A}$ inclusions.

heating of 324 such inclusions (see figure $3 b$ ). In type A inclusions with solids, continuous heating beyond temperatures of disappearance of gas bubble did not lead to dissolution of solids, and the inclusions exploded. Probably, all these solids are captive solids i.e. solids entrapped along with the mineral forming aqueous solution.

All type B inclusions also homogenized in two stages. First, at temperatures between 
$+3.0^{\circ} \mathrm{C}$ and $+19.9^{\circ} \mathrm{C}, \mathrm{CO}_{2}$ phase became homogeneous with the gradual disappearance of gaseous $\mathrm{CO}_{2}$ (see figure 3a). On further heating, dark bubble $\left(\mathrm{CO}_{2}\right.$ phase) gradually expanded to fill up the whole volume of the cavity at temperatures of homogenization varying between 307 and $471^{\circ} \mathrm{C}$, with a mean value of $360^{\circ} \mathrm{C}$ obtained from 15 such inclusions (see figure $3 \mathrm{~b}$ ).

Secondary type $\mathrm{D}$ inclusions homogenized into liquid phase at temperature between 83 and $196^{\circ} \mathrm{C}$ with a mean value of $137^{\circ} \mathrm{C}$ obtained from 211 such inclusions (see figure $3 \mathrm{c}$ ).

\section{Freezing studies}

Freezing studies were carried out on a Linkam TH 600 heating-freezing system to determine the composition, and salinity of entrapped material. Before freezing, the stage was calibrated using distilled water (melting point $=0^{\circ} \mathrm{C}$ ) and $n$-octane (melting point $=-56.6^{\circ} \mathrm{C}$ ) sealed in flat bottomed capillary tubes as standards. Inclusions were first frozen and phase changes were observed during gradual warming.Heating rate close to the expected points of phase changes was kept as low as $0.1{ }^{\circ} \mathrm{C} / \mathrm{min}$ and $0.5^{\circ} \mathrm{C} / \mathrm{min}$.

The liquid in type $\mathrm{A}$ inclusions usually froze at temperatures between -40 and $-60^{\circ} \mathrm{C}$. Accurate recording of the temperature of first melting (temperature of eutectic) is normally difficult and therefore repeated freezing runs were undertaken to determine this temperature as accurately as possible.

Liquid $\mathrm{CO}_{2}$ in types $\mathrm{A}, \mathrm{B}$ and $\mathrm{C}$ inclusions showed considerable resistance to solidification particularly in types $\mathrm{B}$ and $\mathrm{C}$ inclusions. Considerable overcooling (upto $-130^{\circ} \mathrm{C}$ ) was required to solidify liquid $\mathrm{CO}_{2}$ in these inclusions. In types $\mathrm{A}, \mathrm{B}$ and $\mathrm{C}$ inclusions, freezing first produced a small bubble separating gaseous $\mathrm{CO}_{2}$ from liquid $\mathrm{CO}_{2}$ followed by solidification of liquid $\mathrm{CO}_{2}$ at considerably low temperatures. Formation of $\mathrm{CO}_{2}$ hydrate (Clathrate) has been observed by many workers during freezing studies on $\mathrm{CO}_{2}$ bearing inclusions (Roedder 1963; Kelly and Turneaure 1970; Collins $1979 \mathrm{etc}$ ). Clathration is usually recorded with the help of double freezing of such inclusions (Collins 1979), where clathrate freezes out first followed by freezing of aqueous phase. In types $\mathrm{A}, \mathrm{B}$ and $\mathrm{C}$ inclusions despite appreciable amount of detectable $\mathrm{CO}_{2}$ phase, we have not been able to identify clathration. It might be possible that because of the small size of these inclusions $(<20-25 \mu \mathrm{m})$ it was difficult to observe double freezing. Further, in many type B inclusions, the amount of aqueous phase was probably too small to form detectable amounts of clathrate. It should be mentioned that clathration has not been detected in many other $\mathrm{CO}_{2}$ bearing fluid inclusions from other localities (Luckscheiter and Morteani 1980). Heating and freezing data on all types of fluid inclusions are summarized in table 1.

\section{Pressure and temperature conditions of ore formation}

Primary sulphides, as mentioned earlier, are distributed as disseminations, small stringers and veinlets within quartz-feldspar reef. Textural relationship between primary sulphides and gangue (quartz and orthoclase) minerals indicates that sulphides are syngenetic to the bulk of the quartz and feldspar. Hence primary and/or pseudo- 
Table 1. Heating and freezing data (in ${ }^{\circ} \mathrm{C}$ ) for types $\mathrm{A}, \mathrm{B}, \mathrm{C}$ and $\mathrm{D}$ inclusions in quartz.

\begin{tabular}{lccccc}
\hline $\begin{array}{l}\text { Type of } \\
\text { inclusions }\end{array}$ & $T_{m} \mathrm{CO}_{2}$ & $T_{e}$ & $T_{m}$ ice & $T_{h} \mathrm{CO}_{2 \mathrm{~V}-\mathrm{L}}$ & $T_{h \mathrm{~V}-\mathrm{L}}$ \\
\hline A & -56.0 to -56.4 & -22.4 to $-23.4-14.2$ to -1.8 & +17.3 to +30.4 & 210 to $476(\mathrm{~L})$ \\
B & -56.0 to -56.4 & nd & nd & +3.0 to +19.9 & 307 to $471\left(\mathrm{CO}_{2}\right)$ \\
C & -56.0 to -56.4 & nd & nd & +3.7 and +15.6 & nd \\
D & - & nd & nd & - & 88 to $196(\mathrm{~L})$ \\
\hline
\end{tabular}

$T_{m}$ Temperature of melting; $T_{e}$ Temperature of first melting i.e. temperature of eutectic; $T_{h} \mathrm{CO}_{2} \mathrm{~V}-\mathrm{L}$ Temperature of homogenization of $\mathrm{CO}_{2}$ phases; $T_{h \mathrm{~V}-\mathrm{L}}$ Temperature of final homogenization. Letters in brackets represent final phase of homogenization; V-Vapour/gas; L-Liquid; nd-not determined

secondary types A, B and C inclusions observed in quartz, represent mineral-forming solutions responsible for the main episode of ore formation. Secondary type D inclusions are either related to the same mineralization episode or represent any later hydrothermal event superimposed on it.

\subsection{Boiling}

As mentioned earlier types $\mathrm{A}, \mathrm{B}$ and $\mathrm{C}$ inclusions which show highly variable $\mathrm{CO}_{2} / \mathrm{H}_{2} \mathrm{O}$ ratio occupy the same clusters of random inclusions or constitute the same bands of inclusions (see figure 2) indicating that these inclusions are syngenetic to each other. In addition, these inclusions homogenize into different phases (type $A$ into liquid and type B into gaseous) at almost similar temperatures (see figure 3) suggesting that entrapment of these inclusions took place from heterogeneous mineral-forming solutions caused by boiling. Entrapment of different amounts of the immiscible fractions of the boiling solutions resulted in the formation of syngenetic inclusions showing large variation of $\mathrm{CO}_{2} / \mathrm{H}_{2} \mathrm{O}$ ratio. Large variation in the temperature of their final homogenization also supports this suggestion (Ramboz et al 1982). Heterogeneous entrapment i.e. boiling is also indicated by considerable variation of the homogenization temperatures of $\mathrm{CO}_{2}$ phases in these inclusions (see figure 3a).

Experimental studies of $\mathrm{H}_{2} \mathrm{O}-\mathrm{CO}_{2}$ system reveal an immiscibility solvus, with solvus crest at $275^{\circ} \mathrm{C}$ (at $1 \mathrm{kbar}$ ) for pure $\mathrm{CO}_{2}$ and $\mathrm{H}_{2} \mathrm{O}$ mixture (Todheide and Frank 1963 in Hollister 1981). Addition of electrolytes to the mixtures greatly expands the region of immiscibility (Takenouchi and Kennedy 1965). For $6 \mathrm{wt} \%$ salt in the aqueous phase, solvus crest rises to about $420^{\circ} \mathrm{C}$ at $1.5 \mathrm{kbar}$ (Gehrig et al 1969 cited in Hollister 1981). In the case of Malanjkhand ores, $\mathrm{CO}_{2}$-rich saline solutions underwent immiscibility due to boiling, generating almost pure supercritical $\mathrm{CO}_{2}$ coexisting with relatively $\mathrm{CO}_{2}$ poor aqueous solution. Entrapment of mixed proportions of the two immiscible fluids generated inclusions showing large variation in temperatures of homogenization.

\subsection{Composition and salinity of solutions}

Freezing studies of type A inclusions show that solids within these inclusions start dissolving at temperatures between $-22.9^{\circ} \mathrm{C}$ and $-23.9^{\circ} \mathrm{C}$ (table 1). This temperature, 
Table 2. Concentration of $\mathrm{CO}_{2}$ and Bulk molar volumes of entrapped media in Types $\mathrm{A}$ and $\mathrm{B}$ inclusions.

\begin{tabular}{lcccc}
\hline Type & $\begin{array}{c}\text { Vol \% } \\
\text { at } \\
40^{\circ} \mathrm{C}\end{array}$ & $\begin{array}{c}\text { Temperature of } \\
\text { homogenization } \\
\left(\mathrm{Th} \mathrm{CO}_{2} \mathrm{~V}^{\circ}\right)^{\circ} \mathrm{C}\end{array}$ & $\begin{array}{c}\text { Bulk molar } \\
\text { volume } \\
\left(\mathrm{cm}^{3} / \text { mole) }\right)^{* *}\end{array}$ & $\begin{array}{c}\text { Concentration } \\
\text { of } \mathrm{CO}_{2} \\
\left(\mathrm{~mole}^{*}\right)^{* *}\end{array}$ \\
\hline A & 90 & $+17 \cdot 3$ & 20.8 & 2 \\
A & 80 & $+30 \cdot 4$ & $22 \cdot 2$ & 5 \\
B & 40 & $+3 \cdot 0$ & 28.6 & 30 \\
\hline
\end{tabular}

\footnotetext{
* Vol \% of liquid phase estimated visually; ** Bulk molar volume of entrapped fluid and mole \%
} of $\mathrm{CO}_{2}$ determined using curves given by Burruss (1981)

Jhich is known as temperature of eutectic, is sufficiently close to $-22.9^{\circ} \mathrm{C}$, the eutectic temperature in $\mathrm{NaCl}-\mathrm{KCl}-\mathrm{H}_{2} \mathrm{O}$ system (Crawford 1981) which means that the liquid entrapped in these inclusions was sufficiently rich in chlorides of sodium and potassium.

Usually, salinities of aqueous phase in the fluid inclusions are determined using depression of the fusion temperature of ice recorded during freezing of these inclusions. But in all those inclusions, where $\mathrm{CO}_{2}$ phase is also present, formation of clathrate makes residual aqueous phase more saline and depression of the fusion temperature of ice gives relatively higher estimates of salinities. For such inclusions Collins (1979) proposed use of the decomposition temperature of clathrate for the estimation of salinities. In type $A$ inclusions though detectable amount of $\mathrm{CO}_{2}$ is present (table 2), clathration could not be identified. On the other hand, temperature of fusion of ice in these inclusions varied between $-14.2^{\circ} \mathrm{C}$ and $-1.8^{\circ} \mathrm{C}$ with a mean value of $-7.0^{\circ} \mathrm{C}$ obtained from freezing of 22 such inclusions (see figure $3 \mathrm{~d}$ ). This corresponds to a salinity varying from 18 to $2.3 \mathrm{wt} \%$ equivalent of $\mathrm{NaCl}$ with a mean value of $10.5 \mathrm{wt} \%$ equivalent of $\mathrm{NaCl}$ (Potter et al 1978 in Roedder 1984). These values represent maximum salinity assuming that clathration in type $A$ inclusions did occur but could not be identified.

\section{3 $\mathrm{CO}_{2}$ in fluid inclusions}

As mentioned earlier quartz from the mineralized reef contains large number of mixed $\mathrm{CO}_{2}-\mathrm{H}_{2} \mathrm{O}$ and pure $\mathrm{CO}_{2}$ inclusions. Freezing studies of these mixed $\mathrm{CO}_{2}-\mathrm{H}_{2} \mathrm{O}$ (types $\mathrm{A}$ and $\mathrm{B}$ ) inclusions give temperature of melting of $\mathrm{CO}_{2}$ varying betweer $-56.0^{\circ} \mathrm{C}$ and $-56.4^{\circ} \mathrm{C}$ which is close to the temperature of melting of pure $\mathrm{CO}_{2}$ $\left(-56.6^{\circ} \mathrm{C}\right)$. Temperatures of homogenization of $\mathrm{CO}_{2}$ phases in these inclusions have been used to estimate bulk molar volume and $\mathrm{mol}_{\%}$ of $\mathrm{CO}_{2}$ in the entrapped fluid by taking the help of curves proposed by Burruss (1981). These data have been summarized in table 2. Thus, type B inclusions which homogenize with the disappearance of liquid phase at the final temperature of homogenization clearly have fluids of lower density, higher bulk molar volume and higher $\mathrm{mol} \%$ of $\mathrm{CO}_{2}$ in them. The coexisting type $\mathrm{A}$ inclusions that homogenize with the disappearance of gas bubble at the final temperature of homogenization are relatively more dense, and contain lesser amounts of $\mathrm{CO}_{2}(2-5 \mathrm{~mol} \%)$. These results agree with the general trend observed during immiscibility in $\mathrm{CO}_{2}-\mathrm{H}_{2} \mathrm{O}$ and $\mathrm{CO}_{2} \mathrm{H}_{2} \mathrm{O}-\mathrm{NaCl}$ system where $\mathrm{CO}_{2}$ preferentially fractionates into a lower density fluid. 


\subsection{Temperature of formation}

From the preceding discussion it is clear that the primary and/or pseudo-secondary inclusions of type $\mathrm{A}$, type $\mathrm{B}$ and type $\mathrm{C}$ in quartz were formed from $\mathrm{CO}_{2}$-bearing aqueous solution of $\mathrm{NaCl}$ and $\mathrm{KCl}$, boiling during entrapment, i.e. at the time of entrapment vapour pressure of the solution was higher than the confining pressure. As a result, the temperatures of homogenization of these inclusions do not need any pressure correction and these temperatures represent true temperatures of entrapment. Hence, it can be concluded that mineralized quartz-feldspar reef was formed at temperatures between $210^{\circ} \mathrm{C}$ and $476^{\circ} \mathrm{C}$ from hydrothermal solutions that underwent recurrent boiling between temperatures of $307^{\circ} \mathrm{C}$ and $476^{\circ} \mathrm{C}$. More precisely, boiling occurred at around $307^{\circ} \mathrm{C}$ which is the lowest temperature of homogenization at which both types $A$ and $B$ inclusions homogenize into two different phases (type $A$ into liquid and type $B$ into gaseous).

\subsection{Pressure during entrapment}

Figure 4 shows a number of curves representing solubility of $\mathrm{CO}_{2}$ in $\mathrm{NaCl}$ solution. These curves can be used to estimate vapour pressure of $\mathrm{NaCl}$ solution having different amounts of $\mathrm{CO}_{2}$ dissolved in it.

As mentioned earlier, type $\mathrm{A}$ inclusions represent a fluid having a maximum $\mathrm{CO}_{2}$ concentration of $2-5 \mathrm{~mol} \%$ (i.e. 4.5 to $11.3 \mathrm{wt} \% \mathrm{CO}_{2}$ ) and an average salinity of

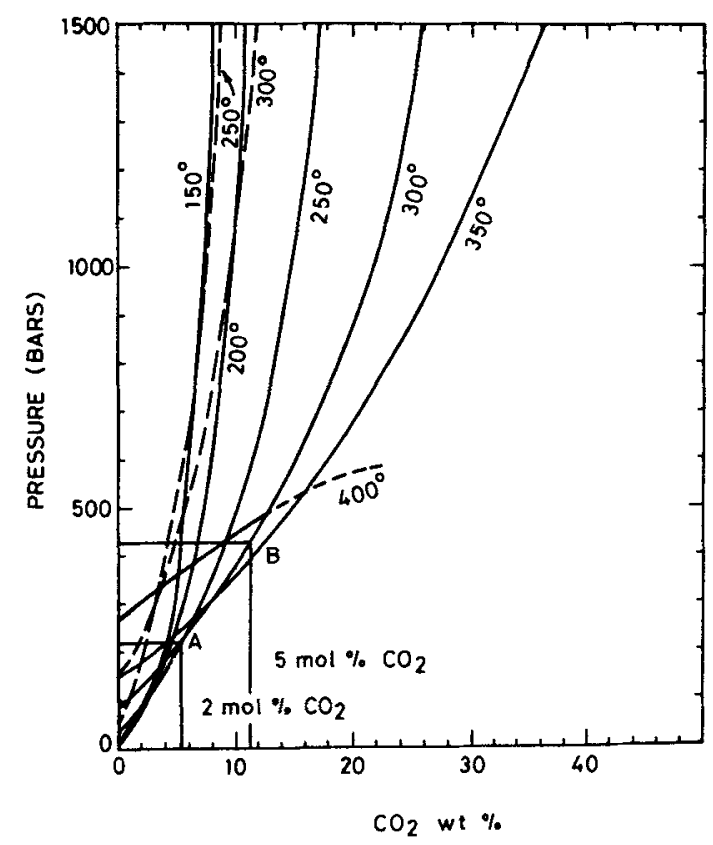

Figure 4. Diagram showing vapour pressure of $\mathrm{CO}_{2}$ bearing $\mathrm{NaCl}$ solutions (modified after Takenouchi and Kennedy 1965). Thick lines are for $6 \mathrm{wt}{ }_{0}^{\circ} \mathrm{NaCl}$ solutions and dashed lines for $20 \mathrm{wt} \% \mathrm{NaCl}$ solutions. 
$10.4 \mathrm{wt} \%$ equivalent of $\mathrm{NaCl}$. The actual salinity, as discussed earlier, might be lower than this. Figure 4 shows that a $6 \mathrm{wt} \% \mathrm{NaCl}$ solution having $2-5 \mathrm{~mol} \% \mathrm{CO}_{2}$ and boiling at $300^{\circ} \mathrm{C}$ would generate a vapour pressure of 225 to 440 bars (points $A$ and B) respectively. These values of pressure are good approximation of pressure during entrapment of type $A$ and syngenetic to the type $B$ and $C$ inclusions from boiling hydrothermal solutions. These pressures correspond to hydrostatic column depths of about 2.25 to $4.4 \mathrm{~km}$ or rock depths of about 1 to $2 \mathrm{~km}$ respectively. It should be mentioned that these values of pressure are only approximate values. Increase in salinity of the solution will bring an appreciable change in these values. For comparison, two curves for $\mathrm{CO}_{2}$ bearing solutions of $20 \mathrm{wt} \% \mathrm{NaCl}$ have also been plotted on the same figure (see figure 4). A $6 \mathrm{wt} \% \mathrm{NaCl}$ solution with $5 \mathrm{~mol} \%$ of $\mathrm{CO}_{2}$ generates a vapour pressure of about 400 bars at $350{ }^{\circ} \mathrm{C}$ but increase in salinity upto $20 \mathrm{wt} \% \mathrm{NaCl}$ enhances this pressure to about 1350 bars.

\section{Geochemical parameters of ore deposition}

It has been shown above that primary ore and gangue minerals were deposited from $\mathrm{CO}_{2}$-bearing $\mathrm{NaCl}-\mathrm{KCl}$ aqueous solutions that were boiling at $307^{\circ} \mathrm{C}$. Hence, to estimate basic geochemical parameters $\left(f_{\mathrm{O}_{2}}, f_{\mathrm{S}_{2}}, \mathrm{pH}\right.$ etc) of ore deposition a $\log f_{\mathrm{O}_{2}}-\log f_{\mathrm{S}_{2}}$ diagram at $300^{\circ} \mathrm{C}$ showing stability fields of main ore and gangue minerals has been calculated (see figure 5). First, a $\log f_{\mathrm{O}_{2}}-\mathrm{pH}$ diagram at $300^{\circ} \mathrm{C}$ was calculated using the method of Barnes and Kullerud (1961). This diagram had fields of dominant aqueous species of sulphur along with contours of $\log f_{\mathrm{S}_{2}}$. The $\log f_{\mathrm{O}_{2}}-\mathrm{pH}$ diagram was then converted into a $\log f_{\mathrm{O}_{2}}-\log f_{\mathrm{S}_{2}}$ diagram in which $\mathrm{pH}$ has been shown as contours of equal $\mathrm{pH}$ values. Stability fields of relevant ore and gangue minerals were then plotted on this diagram. All relevant reactions along with their equilibrium constants have been summarized in table 3.

The primary ores of Malanjkhand are made up of pyrite, chalcopyrite, magnetite and minor amounts of molybdenite with quartz and orthoclase as the dominant gangue minerals. Both gangue and ore minerals as discussed earlier are broadly syngenetic to each other. Sharma (1982), based on partitioning of trace elements between coexisting sulphides concluded that the ore minerals were formed in equilibrium with each other. Thus the syngenetic nature of ore and gangue mineral assemblage helps to put following limits to $f_{\mathrm{O}_{2}}$ and $f_{\mathrm{S}_{2}}$ conditions of ore deposition:

(a) Presence of molybdenite indicates that $\log f_{\mathrm{S}_{2}}$ was $>-20.65 \mathrm{~atm}$.

(b) Absence of pyrrhotite in the ores indicates that $\log f_{\mathrm{S}_{2}}$ was $>-11.6 \mathrm{~atm}$.

(c) Absence of bornite coexisting with pyrite in primary ores indicates that $\log f_{\mathrm{S}_{2}}$ was $<-6.06$ atm.

(d) Presence of equilibrium association pyrite, chalcopyrite and magnetite in ore limits $f_{\mathrm{S}_{2}}-f_{\mathrm{O}_{2}}$ conditions to boundary line $\mathrm{AB}$ in figure 5 which is the line of coexistence of these minerals.

(e) The boundary line between orthoclase and muscovite passing along $\mathrm{pH}=4.5$ contour further narrows down the conditions towards higher $\mathrm{pH}$ values along the line $\mathrm{AB}$, as both quartz and orthoclase, are the dominant gangue minerals in the mineralized reef. Thus, based on the above considerations the following values are obtained: $\log f_{\mathrm{O}_{2}}=-34.4$ to $-30.2 \mathrm{~atm}, \log f_{\mathrm{S}_{2}}=-11.6$ to $-8.8 \mathrm{~atm}, \mathrm{pH}=4.5$ to 6.5 . 


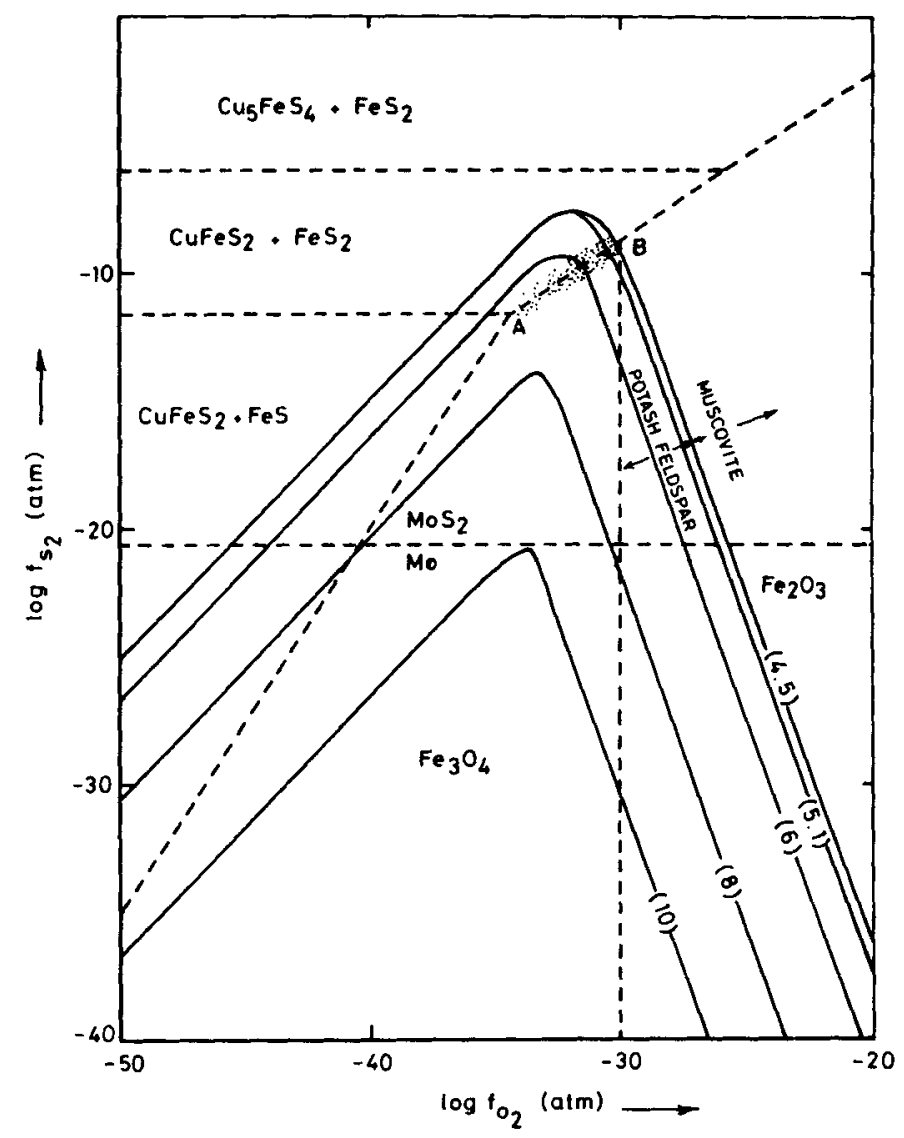

Figure 5. $\log f_{\mathrm{S}_{2}}-\log f_{\mathrm{O}_{2}}$ diagram showing stability fields of main minerals of primary ores from Malanjkhand. Diagram constructed for $T=300^{\circ} \mathrm{C}, P=1 \mathrm{~atm}, \Sigma S=0.01 \mathrm{~m}$. - boundaries between minerals. pH values are written in brackets. Boundary between potash feldspar and muscovite following a pH contour of 4.5 has been drawn for $\mathrm{K}^{+}=0.5$. Dotted area of boundary line $\mathrm{AB}$ represents domain of deposition of primary Malanjkhand ores.

Table 3. Equilibrium constants of relevant reactions.

\begin{tabular}{lc}
\hline Reactions & $\log K_{300^{\circ} \mathrm{C}}$ \\
\hline $3 \mathrm{FeS}+2 \mathrm{O}_{2}(\mathrm{~g})=\mathrm{Fe}_{3} \mathrm{O}_{4}+\frac{3}{2} \mathrm{~S}_{2}(\mathrm{~g})$ & $51 \cdot 04^{a}$ \\
$3 \mathrm{FeS}_{2}+2 \mathrm{O}_{2}(\mathrm{~g})=\mathrm{Fe}_{3} \mathrm{O}_{4}+3 \mathrm{~S}_{2}(\mathrm{~g})$ & $33 \cdot 60^{a}$ \\
$2 \mathrm{FeS}_{2}+\frac{3}{2} \mathrm{O}_{2}(\mathrm{~g})=\mathrm{Fe}_{2} \mathrm{O}_{3}+2 \mathrm{~S}_{2}(\mathrm{~g})$ & $27 \cdot 82^{a}$ \\
$4 \mathrm{Fe}_{3} \mathrm{O}_{4}+\mathrm{O}_{2}(\mathrm{~g})=6 \mathrm{Fe}_{2} \mathrm{O}_{3}$ & $30 \cdot 12^{a}$ \\
$\mathrm{FeS}+\frac{1}{2} \mathrm{~S}_{2}(\mathrm{~g})=\mathrm{FeS}_{2}$ & $5 \cdot 81^{a}$ \\
$5 \mathrm{CuFeS}$ & $6 \cdot 06^{a}$ \\
$\mathrm{Mo}_{2}+\mathrm{S}_{2}(\mathrm{~g})=\mathrm{MoS}_{2}$ & $20 \cdot 65^{b}$ \\
$3 \mathrm{KAl} \mathrm{Si} \mathrm{O}_{3}+2 \mathrm{OH}_{4}+4 \mathrm{FeS}_{2}$ & $\mathrm{KAl}_{3} \mathrm{Si}_{3} \mathrm{O}_{10}(\mathrm{OH})_{2}$ \\
$\quad+6 \mathrm{SiO}_{2}+2 \mathrm{~K}^{+}$ & $8 \cdot 4^{\mathrm{c}}$ \\
\hline
\end{tabular}

${ }^{a}$ Calculated based on equations given in Ripley and Oh:noto (1977); ${ }^{C}$ Calculated based on data from Crerar and Barnes (1976);

${ }^{\circ}$ Calculated based on data in Vaughan and Craig (1978) 


\section{Modes of transportation and factors governing ore deposition}

Freezing studies have shown that hydrothermal solutions entrapped in fluid inclusions were compositionally close to $\mathrm{CO}_{2}$-bearing aqueous solutions of $\mathrm{NaCl}$ and $\mathrm{KCl}$. Hence, it is logical to conclude that basic ore-forming elements were transported mainly as chloride complexes. Such a mode of transportation of ore-forming elements has since long been proved viable both theoretically as well as experimentally (Barnes 1979).

Study of fluid inclusions also revealed that quartz along with primary ore minerals was deposited from hydrothermal solutions that were boiling, leading to separation of a $\mathrm{CO}_{2}$-rich, low-density, low-salinity fluid coexisting with a $\mathrm{CO}_{2}$-poor fluid of higher density and salinity. Boiling has been shown to be one of the main mechanisms of ore deposition in many ore deposits particularly in copper prophyry deposits (Roedder 1984). Boiling causes cooling and increases $\mathrm{pH}$ of solutions making chloride complexes of ore-forming elements unstable (Barnes 1979). According to Crerar and Barnes (1976) when $\mathrm{Fe}$ and $\mathrm{Cu}$ are transported as chloride complexes, an increase of $\mathrm{pH}$ by one unit leads to almost total precipitation of these elements.

\section{Conclusions}

Fluid inclusion and mineral equilibria studies in the Malanjkhand copper deposit have indicated the following:

(i) Mineralized quartz-feldspar reef was formed from $\mathrm{CO}_{2}$-bearing hydrothermal solutions containing appreciable amount of chlorides of sodium and potassium at temperatures between 210 and $476^{\circ} \mathrm{C}$.

(ii) Ore-forming hydrothermal solutions underwent boiling at about $307^{\circ} \mathrm{C}$, which led to the separation of a $\mathrm{CO}_{2}$-rich fluid of low density and salinity that coexisted with another comparatively more saline and dense fluid with less amount of $\mathrm{CO}_{2}$ ( 2 to $5 \mathrm{~mol} \%$ ) dissolved in it.

(iii) Pressure during entrapment from boiling hydrothermal solutions varied between 225 and 440 bars which is equivalent to a hydrostatic column depth of about 2.25 to $4.45 \mathrm{~km}$ or a rock depth of about 1 to $2 \mathrm{~km}$ respectively.

(iv) Ore-forming elements (copper, iron, molybdenum) were transported mainly in the form of their chloride complexes and boiling was the main factor which controlled ore deposition.

(v) Primary ore deposition in the reef was characterized by the following range of $\log f_{\mathrm{O}_{2}}=-30.2$ to $-34.4 \mathrm{~atm} ., \log f_{\mathrm{S}_{2}}=-8.8$ to -11.6 atm and $\mathrm{pH}=4.5$ to 6.5 .

\section{Acknowledgements}

The authors gratefully acknowledge financial support of U.G.C. under a research scheme sanctioned to S.J. We also thank Shri S.S. Subedar, and other geologists of HCL, Malanjkhand Copper Project for necessary permission and cooperation during field work. Authors also thank Dr D A Crerar and the referees for helpful comments. 


\section{References}

Barnes H L 1979 Geochemistry of hydrothermal ore deposits (ed) H L Barnes (New York: John Wiley) p. 440 Barnes H L and Kullerud G 1961 Econ. Geol. 56648

Burruss R C 1981 Fluid inclusions: Applications to petrology (eds) L S Hollister and M L Crawford (Calgary: MAC short course handbook) p. 59

Collins P L F 1979 Econ. Geol. 741435

Crawford M L 1981 Fluid inclusions: Applications to petrology (eds) L S Hollister and M L Crawford (Calgary: MAC short course handbook), p. 75

Crerar D A and Barnes H L 1976 Econ. Geol. 71772

Hollister L S 1981 Fluid inclusions: Application to petrology (eds) L S Hollister and M L Crawford (Calgary: MAC short course handbook) p. 1

Kelly W C and Turneaure F S 1970 Econ. Geol. 65609

Luckscheiter B and Morteani G 1980 Lithos 1361

MacDonald A J and Spooner E T C 1981 Econ. Geol. 761248

Narang J L, Sharma R S, Mathur S M, Muktinath 1979 Geol. Survey. India. Misc. Pub. 34113

Ramboz C, Pichavant M, Weisbrod A 1982 Chem. Geol. 3729

Rao S K L 1974 Indian Mineral. 1828

Ripley E M and Ohmoto H 1977 Econ. Geol. 721017

Roedder E 1963 Econ. Geol. 58167

Roedder E 1984 Fluid inclusions (Washington: M S A Reviews in Mineralogy 12) pp. 644

Sharma R N 1982 Geochemistry and genesis of the copper-sulphide deposit of Malanjkhand; Ph.D. thesis (unpublished), University of Roorkee, Roorkee

Sharma R K and Kumar R 1969 Indian Miner. 2323

Takenouchi S and Kennedy G C 1965 Am. J. Sci. 263445

Tripathi C 1979 Geol. Sur. India Misc. Pub. 34161

Vaughan D J and Craig J R 1978 Mineral chemistry of metal sulphides (Cambridge: University Press) pp. 493. 